\title{
Enforcement of labor market regulations: heterogeneous compliance and adjustment across gender
}

Mariana Viollazid

\author{
Correspondence: mviollaz@cedlas. \\ org \\ CEDLAS, Facultad de Ciencias \\ Económicas, UNLP, Calle 6 entre 47 \\ y 48, Oficina 312, La Plata, Argentina
}

\begin{abstract}
This paper explores microdata from Argentine household surveys to analyze how changes in the enforcement of labor regulations affect the compliance level and other labor outcomes among men and women. Using information of the highly decentralized labor inspection system in Argentina, I construct an enforcement measure with variation at the province, sector, and time level (share of inspected firms) which I instrument using a measure of the arrival cost of labor inspectors to the firms. The main findings reveal that when enforcement increases, the compliance with mandated benefits and formal wages increase among men, while informal wages decline. Among women, the compliance level declines jointly with informal wages. These heterogenous impacts are explained by labor regulations that make formal and informal men more substitutable in the production process than formal and informal women.
\end{abstract}

Keywords: Enforcement of labor regulations, Compliance with labor regulations, Gender, Argentina

JEL classification: J16, J63, J88, K31

\section{Introduction}

In Argentina, labor market regulations are extensive and the social security system has a de jure universal coverage. Most workers' rights are established in the National Constitution, while labor relationships are regulated by different laws. However, as in most developing countries, compliance with labor regulations is low in Argentina. According to workers' report on their own working conditions, in 2015, around 31\% of wage employees did not receive pension contributions, health insurance, and the annual extra monthly pay and were not entitled to paid vacation time (SEDLAC 2017). These figures suggest that there is a large difference between the written regulations and its effective implementation in the country.

Strict labor regulations jointly with an imperfect enforcement can generate incentives to the firms for not complying with the labor law (Basu et al. 2010). That will depend on firms' evaluation of the costs and benefits of evading the regulations (the expected monetary fine versus reduced labor costs). When the compliance with labor regulations is low, the enforcement of the rules becomes a concept that is closer to the regulatory environment that firms and workers face (Almeida and Carneiro 2009).

(C) The Author(s). 2018 Open Access This article is distributed under the terms of the Creative Commons Attribution 4.0 International License (http://creativecommons.org/licenses/by/4.0/), which permits unrestricted use, distribution, and reproduction in any medium, provided you give appropriate credit to the original author(s) and the source, provide a link to the Creative Commons license, and indicate if changes were made. 
Therefore, firms are expected to react to variations in the enforcement level, even when the written regulation does not change.

In this paper I explore microdata from Argentine household surveys for the period 2005-2011 to analyze (i) how changes in the enforcement of labor market regulations affect different indicators of compliance with the labor law among men and women and (ii) how changes in enforcement generates adjustments of some labor outcomes (different than the compliance level) for men and women separately. I take advantage of the highly decentralized labor inspection system in Argentina which allows me to construct an enforcement measure (number of inspected firms per hundred formal firms) with variation at the province, productive sector, and time level. The econometric strategy links indicators of compliance with labor regulations and other labor market outcomes such as hourly wages, percentiles of the wage distribution, indicators of the provision of non-mandated benefits, and the structure of occupation by employment categories (wage employment versus self-employment), with the enforcement measure and with a rich set of individual socioeconomic and labor characteristics, and economic, institutional, and development characteristics of Argentine provinces.

The mechanisms analyzed in this paper are the following. When formal firms face stricter enforcement, the cost of not complying with labor regulations becomes higher. The increased cost of informal employment, i.e., workers not receiving mandated benefits, leads firms to comply with the rules by substituting formal employees for informal employees (substitution effect) and to reduce the size of the labor force (scale effect). The increased compliance may impact men and women differently. First, labor regulations usually present some differences across gender, and that is the case in Argentina. Second, differences in some labor characteristics, such as average monthly earnings, may lead firms to avoid labor regulation among women more than men or the other way around. Adjustments in the size of the labor force may also have a different impact on men and women. Firms may prefer to lay off women more than men because their severance pay will be lower, i.e., women's average tenure and monthly earnings are usually lower in comparison to men. An additional impact associated with the scale effect is that workers who lose their jobs may offer their hours of work to informal firms. This effect is possible because labor inspections are focused on formal firms in Argentina. The increased labor costs resulting from stricter enforcement can lead firms to make additional adjustments which can also differ among men and women. They can reduce hourly wages or decrease the level of non-mandated benefits, such as meals and housing.

The main challenge to the estimation of the relationships of interest is that the enforcement measure is probably endogenous. To deal with this problem, I implement an instrumental variable strategy. The proposed instrument is a measure of the arrival cost of labor inspectors to the firms. Labor inspectors travel by car from the inspection agencies to the firms to be inspected. A combination of the extension of the road network and the traffic in each province provides a measure of the arrival cost to the firms.

Results reveal very different effects of an increase in the degree of enforcement on the compliance level and other labor market outcomes among men and women. Higher enforcement leads firms to increase compliance with labor regulation among men. The shares of male wage employees covered by social security (pensions and health 
insurance) and employment regulations (annual extra monthly wage, paid vacation time, paid sickdays, wage equal or above the minimum and working hours equal or below the legal maximum) increase at the province-sector level, i.e., firms substitute formal wage employees for informal wage employees. Formal wages increase, informal wages decline, and self-employed men become wage earners to take advantage of the increase in the provision of mandated benefits. Among women, higher enforcement leads to a reduction in the provision of mandated benefits at the province-sector level. The scale effect dominates among them, and the decline in formal firms' demand for formal and informal female wage employees leads to formal and informal wage reductions for women (although not significant for formal wages). Laid-off women move to informal firms where they do not receive mandated benefits and self-employed women become informal wage employees, probably attracted by the probability of obtaining better employment conditions in the future due to higher enforcement. All these findings are in line with the functioning of a two-sector economy model with competitive markets and no rigidities.

The topic of gender differences in the analysis of labor market regulations is of clear importance for both developed and developing countries. I focus the empirical work on Argentina for three reasons. First, the availability of data allows me to construct a measure of enforcement with variation across provinces, sectors, and overtime for the period 2005-2011, when there is also microdata at the individual level on a wide set of mandated benefits for wage employees, some non-mandated benefits and hourly wages. With this data, I can test for men and women how the compliance with labor regulations reacts when the enforcement measure changes, and how other labor outcomes respond, probably due to firms' need of adjustment. Second, the fact that the labor rules being enforced are common to all Argentine provinces generates an ideal framework to evaluate the effects of changes in the enforcement measure on labor outcomes using the province variation of the data. Third, equality of opportunities between men and women has been placed at the top of the policy agenda in recent years. The elimination of any type of violence against women, including the discrimination at the workplace, has been part of Argentine Congress meetings which is discussing laws in that direction.

This paper makes important contributions to the literature analyzing heterogeneous labor market effects of labor regulations across gender, and to the literature studying the effects of enforcement of the labor law (not the law by itself) on labor outcomes. First, to my knowledge, there is no evidence linking the enforcement of labor regulations to labor outcomes of men and women, or using simultaneously the variation of an enforcement measure across geographic locations, economic sectors, and over time. Second, the results provide evidence on how the regulatory environment can impact the decisions that firms and workers make about participating in the informal sector of the economy. Finally, the empirical findings have important policy implications in terms of gender equality in the labor market.

The rest of the paper proceeds as follows. Section 2 reviews the literature while Section 3 provides a description of the labor inspection system in Argentina. Section 4 discusses the theoretical mechanisms at play in the estimation of the relationship between enforcement of labor regulations and labor market outcomes for men and women. Section 5 presents the empirical strategy while Sections 6 and 7 discuss the results. Section 8 concludes. 


\section{Literature review}

This paper relates to three important literatures. First, this paper is related to studies analyzing the impacts of labor regulations on labor market outcomes in a broad sense, i.e., level of compliance with the labor law and other labor outcomes, in a withincountry context. These studies have found that stricter labor regulations are associated with reductions in output, employment, investment, and productivity in the formal sector, declines in job turnover, and output increases in the informal sector (Besley and Burgess 2004; Mondino and Montoya 2004; Kugler 2004; Micco and Pagés 2006). From this strand of literature, this paper is closely related to studies looking at heterogeneous impacts for different population groups. The evidence is not conclusive when it comes to gender differences. Betcherman (2013) provides a detailed survey on the effects of labor regulations on labor market outcomes for men and women. The within-country findings show that stricter job security regulations lead to a reduction in the probability of employment of women relative to men and a movement out of wage employment and into self-employment (Montenegro and Pagés 2004), and lower reductions in earning for women than men (Mondino and Montoya 2004). For the maternity leave specifically, the findings indicate that there is a wage penalty for women depending on the length of the leave (Gindling and Crummett 1997). Regarding the minimum wage legislation, most studies have found a negative employment effect among adult women (Feliciano 1998; Arango and Pachón 2004), with the exception of Montenegro and Pagés (2004), who found that women benefit from minimum wage policies, especially the young. Finally, unions and collective bargaining lead to a positive effect on wages which is larger for women than men (Aidt and Tzannatos 2002), and to larger increases in male unemployment than female unemployment when collective bargaining are more decentralized (Feldmann 2009).

Second, this paper is related to the literature analyzing the relationship between enforcement of labor regulations and labor market outcomes. The large gap between the written regulations and the level of compliance has led to the emergence of studies emphasizing the importance of enforcement of the labor law. These studies use the variation in the enforcement of labor regulations rather than or in addition to changes in the regulation itself to identify effects on labor outcomes. Within country studies have concluded that higher enforcement of the labor law reduces firms' size and possibly productivity (Almeida and Carneiro 2009), decreases job creation and increases job destruction (Almeida and Poole 2017), increases the compliance with labor market regulations (Ronconi 2010; Almeida et al. 2013) or does not have any effect on it (Bhorat et al. 2012; Viollaz 2018), increases formal employment and nonemployment, reduces informal employment, leads to a fall in formal wages at the top of the wage distribution and to informal wage increases (Almeida and Carneiro 2012), and reduces deprovision of non-mandated benefits (Almeida et al. 2013).

Third, this paper relates to the literature linking labor regulations and taxes to the size of the informal sector (De Soto 1989; De Paula and Scheinkman 2006), directly or indirectly through the effect of enforcement (Loayza et al. 2005). Inside the literature on labor informality, this paper is also close to studies conceptualizing the informal sector as a non-homogenous sector, where easy entry and low wage activities coexist with other activities that have barriers to entry, and where the linkages of these two types of activities with the formal sector is very different (Fields 2005). 


\section{Labor regulations and labor inspections in Argentina}

\subsection{Labor regulations and workers' rights}

In Argentina, most workers' rights are established in the National Constitution and labor relationships are regulated by different laws. Wage employees who are registered in the formal register of labor relationships are entitled to several benefits including, among others, a minimum monthly wage, an annual extra monthly wage, paid vacation time, a maximum of eight working hours a day and $48 \mathrm{~h}$ a week, retirement and health insurance benefits, a paid maternity leave of 90 days and a paternity leave of 2 days, advance notice and severance payment, family allowances, and unemployment insurance.

The level of compliance with labor market regulations is far from perfect in Argentina. During the 1990s and the beginning of the 2000s, the percentage of wage employees who received legally mandated benefits fell systematically for both men and women (Fig. 1). This was a period characterized by a gradual process of agreement between workers' unions and employers with the objective of increasing the flexibility in labor relationships. Since 2003, the percentage of wage employees receiving mandated benefits showed a positive trend reaching more than $60 \%$ of coverage in 2015 . This pattern was probably related to the better performance of the economy and also to changes in the labor inspection system through the Labor Regulation Law passed in 2004 (MTEySS 2013). Along the entire period depicted in the figure, the percentages of male wage employees covered by social security or employment benefits were always above the percentages for women.

\subsection{Labor inspection system}

The Labor Regulation Law of 2004 set up the Labor Inspection System, or LIS for short, with the objective of monitoring the compliance with labor and social security regulations ${ }^{1}$. This system intends to guarantee the labor rights established in the National Constitution and international labor agreements supported by Argentina. The law establishes a shared faculty to exert control and assess the compliance with labor laws between the

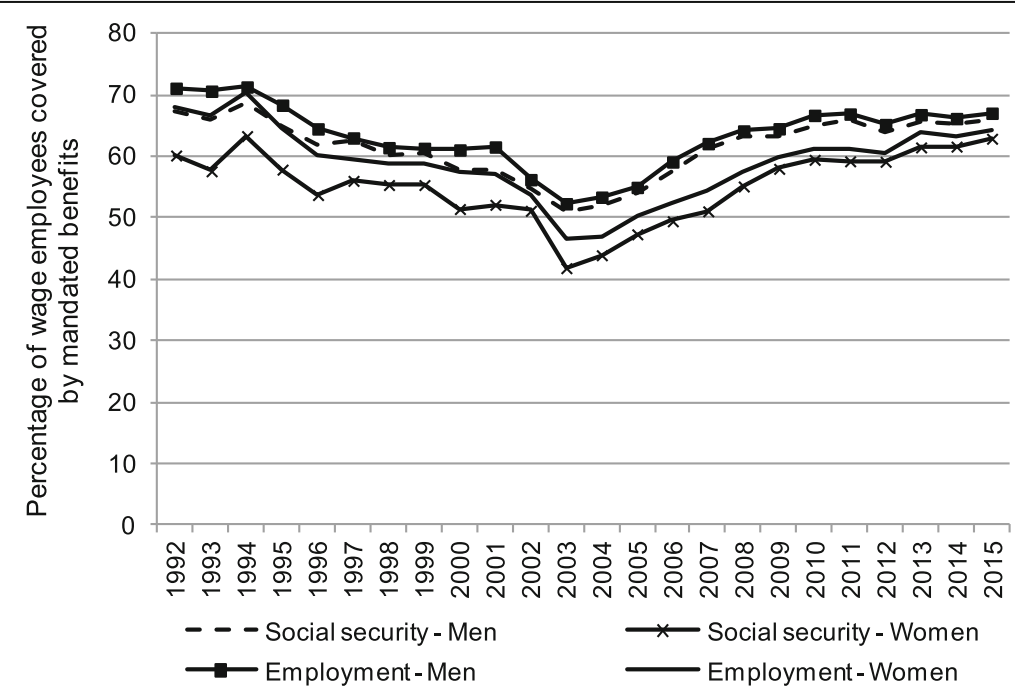

Fig. 1 Percentage of compliance with social security and employment benefits by gender. Wage employees. 1992-2015. Source: Own elaboration based on SEDLAC (2017) 
National Ministry of Labor, the 23 provinces, and the Ciudad Autónoma de Buenos Aires (CABA), which is the capital of the country and an autonomous district ${ }^{2}$.

Labor inspections are decentralized in 39 local inspection agencies which are spread throughout the country and grouped in seven regional agencies. Each province has at least one local inspection agency in its jurisdiction and their functions extend only to each province's territory ${ }^{3}$.

Every quarter, regional agencies receive recommendations from the National Ministry of Labor regarding the activities and areas where the inspections should be focused. Regional agencies jointly with local inspection agencies organize the inspection activities geographically and by economic sector according to the recommendations received, the availability of resources, and past experience. Since the implementation of the LIS, local inspection agencies have learnt about the activities operating in their jurisdictions, the amount of workers participating in these sectors, and the seasons of more activity, allowing the adjustment of the inspection's plans. In fact, the detection of non-registered workers increased since 2005 despite the general reduction in the number of inspected firms (Fig. 2) (MTEySS 2013).

Labor inspections are focused on formal firms in expansionary economic activities that have contributory capacity in order to avoid the penalties to go to weaker sectors (MTEySS 2013) ${ }^{4}$. In order to reduce inspectors' opportunities to select the firms in a discretionary manner, they receive clear instructions from the local agencies about the number of firms and workers to assess and the number of non-registered workers to detect. Inspectors travel from the local agency to the firms to be inspected by car. Since the creation of the LIS, local and regional agencies have received vehicles (cars and vans) easing the inspection activities.

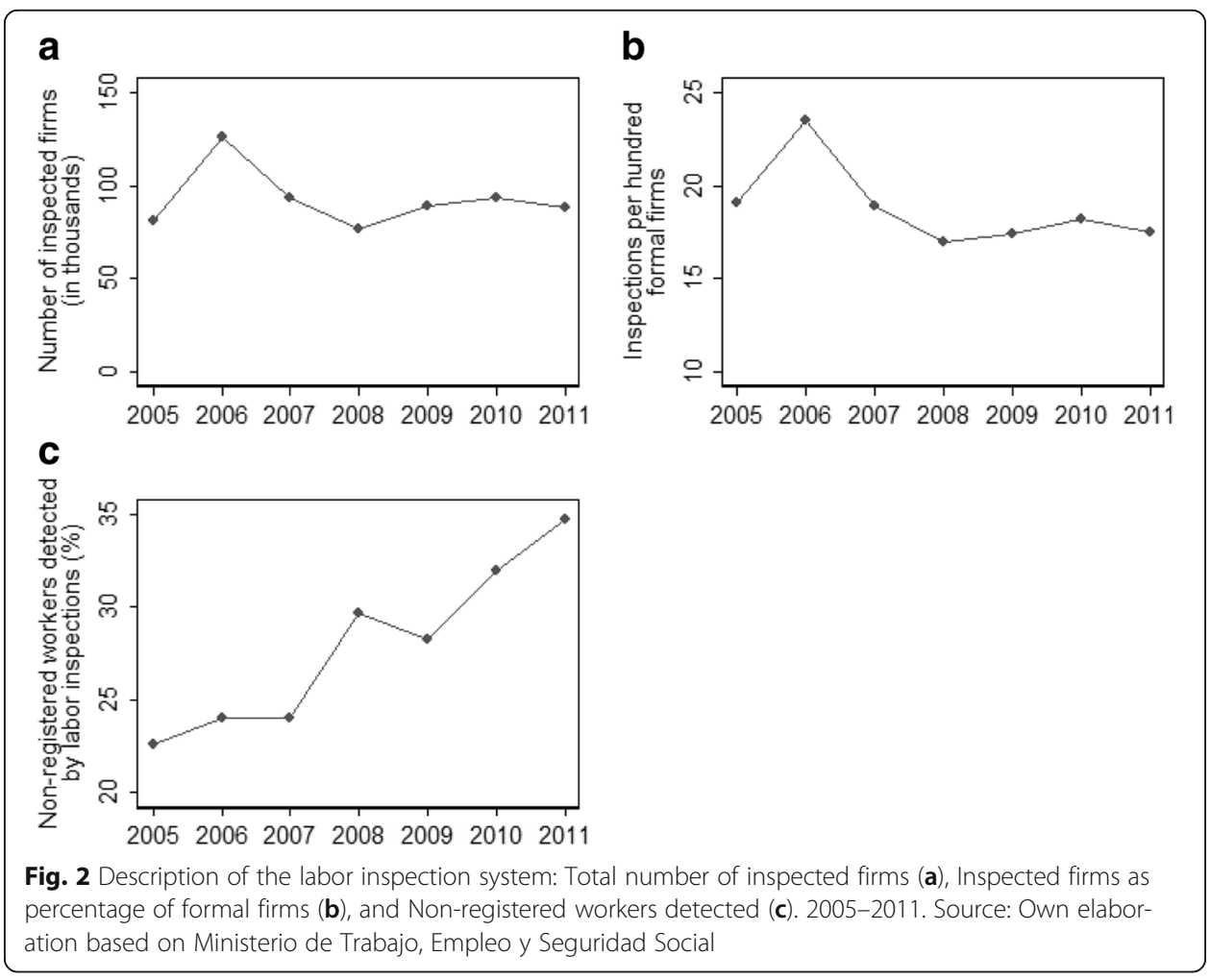


The violations of labor regulations are classified according to their severity-there are minor, serious, and very serious violations. When a situation of non-compliance with the law is detected, a case file is opened and the employer has the opportunity to present evidence in its defense. With this information and the result of a second inspection, the Resolution Office determines if the employer should be penalized. The penalties consist of economic fines, which amount depends on the severity of the violation, and the close down of the firm in case of reoccurrence of very serious violations. If the employer solves the irregularity by the moment of the deposition, the amount of the penalty is reduced.

\subsection{Enforcement of labor regulations}

The measure of enforcement of labor market regulations in this paper is the number of inspected firms per hundred formal firms in each of the 24 provinces, 10 productive sectors and year, from 2005 to 2011. Enforcement is expected to vary at the province and sector level since labor inspections are planned by the local inspection agencies considering the productive structure of local economies, the number of workers participating in the main activities and their seasonality, among other factors.

Institutional and development factors can also play a role. In certain provinces, labor inspectors could be more prone to participate in dishonest deals. There is evidence on reports against labor inspectors who ask for money in exchange for not inspecting certain firms. The evidence also points out different "patterns" of enforcement across provinces. For example, inspectors in Córdoba are highly dependent on labor unions, while in CABA they rely on non-union civil organizations for enforcement (Amengual 2014). This evidence indicates that institutional and development characteristics of the provinces are close determinants of the enforcement level and probably of the level of compliance with labor regulations as well.

Figure 2 reports the time series of some variables related to the inspection system between 2005 and 2011. Panels (a) and (b) show, for the country as a whole, the number of inspected firms and the number of inspected firms per hundred formal firms respectively. Both variables present the same overall pattern, with a reduction over time, especially between 2006 and 2011. As mentioned in the previous section, since the Labor Regulation Law, inspections have been adjusted using information from past experiences in order to achieve the same number of non-registered workers through the inspection of fewer firms (MTEySS 2013). This can be seen in panel (c), which shows the increase over time in the number of non-registered workers detected as a percentage of the total number of inspected workers.

Figure 3 shows the variation in the measure of enforcement across provinces, sectors, and over time. Panels (a) and (b) present changes in the enforcement level between some selected consecutive years for each of the 24 provinces and 10 sectors respectively. The figure shows an important degree of variability in enforcement changes both across provinces and sectors. In some years, the enforcement measure increased in most provinces and sectors although with different intensity across them, e.g., 2005-2006, while in some others it decreased, e.g., 2007-2008. Figure 3 also shows that there is no association between the annual changes in the enforcement measure and the initial structure of employment by gender (panel c) and its annual changes (panel d). 


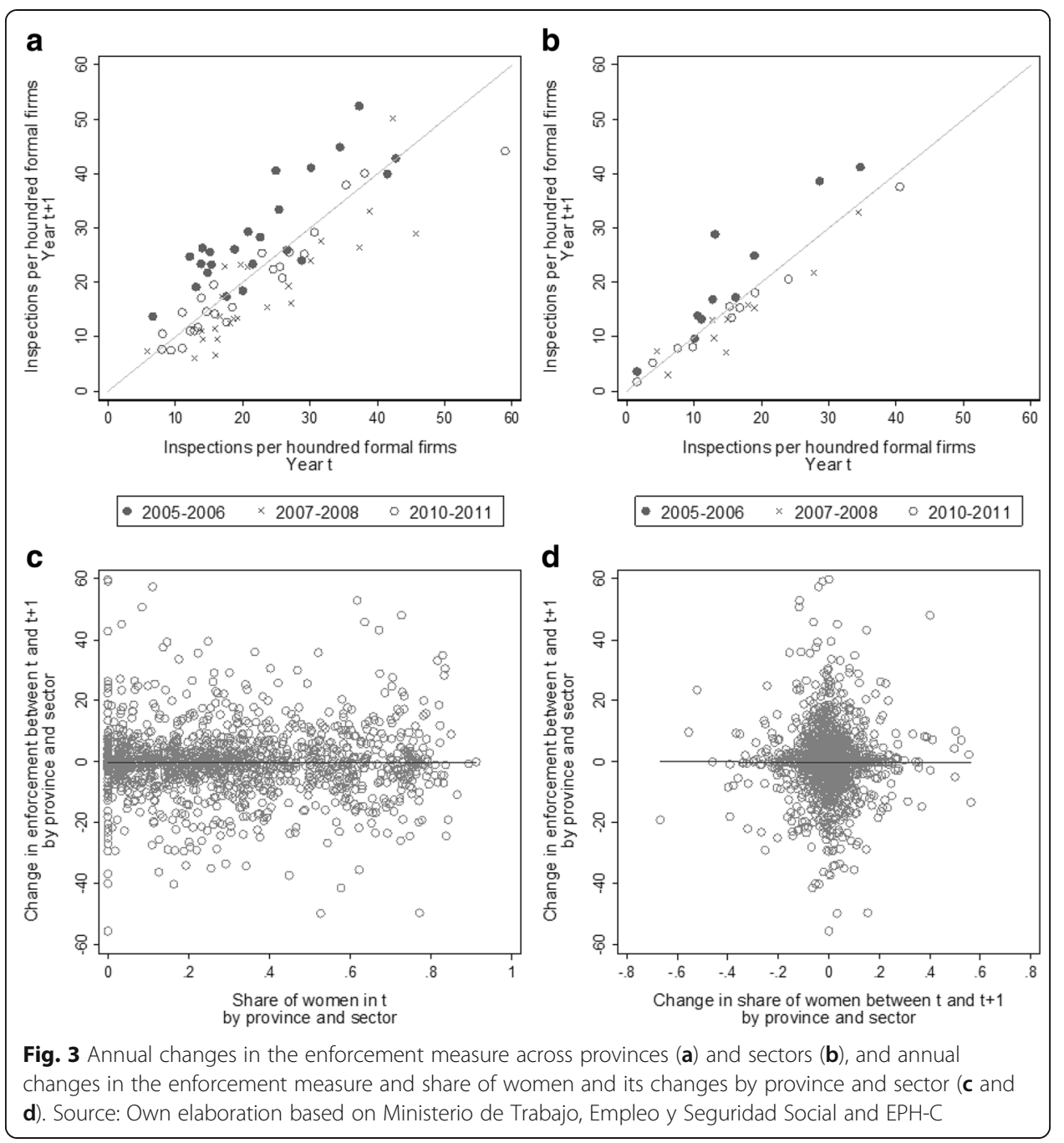

\section{Theoretical mechanisms}

I consider a representative profit maximizing formal firm which operates in a two-sector economy with competitive markets and no rigidities and chooses the number of male and female employees given a set of factors such as technology and capital stock. In a context of imperfect enforcement, the firm can decide to comply with labor regulations or to evade them. As a result, the firm chooses how many of four imperfect substitute-types of workers to hire: formal men, informal men, formal women, informal women. Formal employees receive mandated benefits, while informal employees do not.

When enforcement becomes stricter (labor inspections increase as a percentage of the total number of formal firms), the cost of not complying with labor regulations increases for the firm: the probability of being detected and penalized becomes higher. The increased cost of informal employment leads the firm to (i) comply with the rules by substituting formal employees for informal employees (substitution effect) and (ii) reduce the level of production and the size of the labor force (scale effect) (Micco and Pagés 2006; Almeida and Carneiro 2009).

The increase in compliance (substitution effect) may impact men and women differently. Firms may prefer to increase the level of compliance among women because 
some labor regulations are cheaper for them. For instance, the contributions to the pension and health insurance systems tend to be lower among women as they are a percentage of monthly earnings. On the other hand, firms may prefer to increase the level of compliance among men because women usually enjoy a longer maternity leave.

Adjustments in the size of the labor force (scale effect) may also impact men and women differently. The decline in women employment can be larger than the decline for men (given a reduction in labor demand) due to the larger female labor supply elasticity (Montenegro and Pagés 2004). Firms may also prefer to lay off women more than men because their severance pay will be lower, i.e., women tend to receive lower monthly earnings and have lower average tenure in comparison to men (for a given age $)^{5}$. On the other hand, firms may prefer to have more women than men in their labor force because their higher turnover rates imply that women will probably quit before attaining a high level of tenure, reducing future severance payment costs (Pagés and Montenegro 1999).

An additional impact associated with the scale effect is that workers who lose their jobs may offer their hours of work to informal firms which are not inspected. The shift in employment toward informal firms may depend on workers' valuation of the mandated benefits being enforced (Almeida and Carneiro 2012; Almeida et al. 2013). Considering women as secondary workers, they are expected to accept a job without mandated benefits more than men, because the gain from these benefits is lower if another member of the household already has them, i.e., their husbands (Galiani and Weinschelbaum 2012). Because the household survey data of Argentina does not contain information on the formality status of the firm where each person is employed, this impact cannot be tested directly ${ }^{6}$. However, if the share of wage employees receiving mandated benefits at the province-sector level falls with an increase in enforcement, that will be interpreted as an expansion of employment in informal firms (which are not a target of labor inspections). The reasoning follows the expected reaction of firms when faced with an increase in enforcement. Formal firms that were not complying with all or some dimensions of the mandated benefits for some of their workers are expected to increase the level of compliance, but never to decrease it (substitution effect). Firms can also reduce the size of the labor force. Laid-off workers are the ones who may offer their hours of work to informal firms.

Reductions in firms' size may induce changes in the composition of employment by employment category as well. On the one hand, laid-off workers may switch from being wage employees to self-employment. On the other hand, a higher compliance level may increase wage employment which is now more attractive.

Higher labor costs resulting from an increase in compliance can lead firms to make an additional adjustment. Firms can switch to a capital-intensive technology avoiding the increase in labor costs and the reduction in the production level (Loayza 1996) ${ }^{7}$. The level of investment and labor productivity can also be negatively affected (Besley and Burgess 2004). Firms can also adjust by affecting some job attributes. They can reduce hourly wages or the provision of non-mandated benefits, such as meals and housing. Reductions in hourly wages can affect women more than men because women can be considered "outsiders" with less bargaining power and less negotiating abilities (Montenegro and Pagés 2004). However, the final effect on hourly wages will also 
depend on the reallocation of workers between the formal and informal sectors of the economy. Reductions in the provision of non-mandated benefits such as food and housing are also expected. This set of benefits should be easier to adjust for firms if they are provided voluntarily. However, if the provision of non-mandated benefits consists of an in-kind part of the monthly pay, the expected effect of an increase in enforcement is not clear. Firms may prefer to increase in-kind payments as that will provide them with more liquidity to face the increase in labor costs ${ }^{8}$.

\section{Empirical strategy}

I use information from the Encuesta Permanente de Hogares Continua, Argentine household survey, from 2005 to 2011 where wage employees report their own working conditions. I perform the analysis separately for men and women. The sample of men includes men aged 16 to 65 (legislated retirement age for men), while the sample of women includes those aged 16 to 60 (legislated retirement age for women). The sample comprises wage employees from the private sector who are employed in the productive sectors inspected by the LIS.

Table 1 presents some sample statistics for the main variables used, while the Appendix provides details on variables' definition. Men and women in the sample have almost the same age on average (36 years), women are more educated that men (two more years of education) and have a higher coverage of social security and employment benefits than men $^{9}$. Around $69 \%$ of women enjoy social security coverage, while the figure is $62 \%$ for men. The gender difference is larger when analyzing the coverage of employment regulations: $48 \%$ for women and $36 \%$ for men. Men receive non-mandated benefits (housing, meals, and products) with a higher probability than women. Men tend to work more in small firms and in agriculture and manufacturing sectors in comparison to women. Women receive higher hourly wages than men regardless of their formality status, i.e., whether they receive mandated benefits or not, but monthly labor earning are higher for men.

The main specification regresses different measures of compliance with labor market regulations and other labor outcomes for individual $i$, in province $p$, in productive sector $s$, and year $t$ ( $Y_{i p s t}$ in Eq. (1)) on the measure of enforcement for province $p$, productive sector $s$, and year $t$, which is defined as the logarithm of the number of inspected firms per hundred formal firms $\left(E_{p s t}\right)$.

$$
Y_{i p s t}=\beta X_{i p s t}+\gamma E_{p s t}+\alpha W_{p t}+\delta_{p} I_{p}+\delta_{s} I_{s}+\delta_{t} I_{t}+\delta_{p t}\left(I_{p} * T_{t}\right)+\varepsilon_{i p s t} .
$$

The outcome variables considered in the analysis are as follows: (i) an indicator variable of compliance with social security regulations (equal to one if the wage employee receives contributions to the pension and health insurance systems), (ii) an indicator of compliance with employment regulations (equal to one if the wage employee receives paid vacations, annual extra monthly wage, paid sick days, earns at list the minimum wage, and works no more than the maximum of weekly hours), (iii) other labor outcomes such as hourly wages, percentiles of the hourly wage distribution, non-mandated benefits (indicators of housing, food, and other products), and (iv) an indicator of wage employment where selfemployment is the omitted category. The individual characteristics included as control variables ( $X_{i p s t}$ in Eq. (1)) are age and age squared, indicators for 
Table 1 Summary statistics

\begin{tabular}{|c|c|c|c|c|c|}
\hline & Women & Men & & Women & Men \\
\hline \multirow[t]{2}{*}{ Age } & 35.84 & 36.16 & Employed on large-size firms (\%) & 47.54 & 47.33 \\
\hline & $(11.03)$ & $(12.09)$ & & $(49.94)$ & $(49.929)$ \\
\hline \multirow[t]{2}{*}{ Years of education } & 12.96 & 10.77 & Employed in agriculture (\%) & 0.62 & 1.96 \\
\hline & (3.3) & $(3.67)$ & & (7.83) & (13.86) \\
\hline \multirow{2}{*}{$\begin{array}{l}\text { Social security regulations } \\
\text { coverage (\%) }\end{array}$} & 69.28 & 62.32 & Employed in manufacturing sector (\%) & 12.29 & 22.55 \\
\hline & $(46.13)$ & $(48.46)$ & & $(32.83)$ & $(41.79)$ \\
\hline \multirow{2}{*}{$\begin{array}{l}\text { Employment regulations } \\
\text { coverage (\%) }\end{array}$} & 48.09 & 35.77 & Employed in services sector (\%) & 87.09 & 75.49 \\
\hline & $(49.96)$ & $(47.93)$ & & $(33.53)$ & $(43.01)$ \\
\hline \multirow[t]{2}{*}{ Receives free meals (\%) } & 15.45 & 16.30 & Formal hourly wage & 7.66 & 7.08 \\
\hline & $(36.14)$ & $(36.94)$ & & $(5.76)$ & $(6.94)$ \\
\hline \multirow[t]{2}{*}{ Receives housing (\%) } & 0.39 & 1.58 & Informal hourly wage & 4.45 & 4.05 \\
\hline & $(6.26)$ & $(12.48)$ & & $(4.99)$ & $(4.98)$ \\
\hline \multirow[t]{2}{*}{ Receives products (\%) } & 2.23 & 2.69 & Formal monthly earnings & 1093 & 1291 \\
\hline & $(14.76)$ & $(16.17)$ & & (658) & $(1058)$ \\
\hline \multirow{2}{*}{$\begin{array}{l}\text { Employed on small-size } \\
\text { firms (\%) }\end{array}$} & 20.34 & 23.89 & Informal monthly earnings & 537 & 669 \\
\hline & $(40.25)$ & $(42.64)$ & & (509) & (615) \\
\hline \multirow{2}{*}{$\begin{array}{l}\text { Employed on medium-size } \\
\text { firms (\%) }\end{array}$} & 32.12 & 28.78 & & & \\
\hline & $(46.69)$ & $(45.28)$ & Number of observations & 83,906 & 148,166 \\
\hline
\end{tabular}

Source: Own elaboration. Notes: Sample averages and standard deviations between parentheses. The sample includes female and male wage employees aged 15-60 and 15-65 respectively, employed in private firms in sectors targeted by the inspection system. Variables are defined in Table 11 in the Appendix

educational level, marital status, size of the firm where individual $i$ is employed, and the number of children at home ${ }^{10}$.

Several variables at the province level with variation over time are included in different specifications to control for characteristics that can be correlated with the level of enforcement and can affect the level of compliance as well ( $W_{p t}$ in Eq. (1)). These variables include the logarithm of social per capita expenditure and the primary result (total incomes minus primary expenditures) as a percentage of total incomes. These controls are justified by the heterogeneous political business cycles of the provinces (Piore and Schrank 2008; Murillo et al. 2011; Ronconi 2012); the logarithm of the percentage of absenteeism in provincial elections. This variable intends to control for the quality of provincial institutions; the logarithm of the population, the logarithm of per capita household income, the unsatisfied basic needs poverty indicator, and the logarithm of building permits per capita. These variables capture the provinces' development level (first three variables), and control for demand shocks (last variable). All the specifications include province, sector, and year fixed effects $\left(\delta_{p}, \delta_{s}\right.$, and $\delta_{t}$ in Eq. (1)), while one of the specifications also adds province-specific time trends $\left(I_{p} * T_{t}\right.$, where $T_{t}$ is a categorical variable). The standard errors are clustered at the province and sector levels.

There are reasons to believe that $E_{p s t}$ is correlated with the error term in Eq. (1). First, a low level of compliance with labor regulations can result in a higher level of 
enforcement. Second, the enforcement level can be correlated with unobserved institutional and development time-varying characteristics at the province level (not captured by the province fixed effects or province-specific time trends), generating a spurious correlation with compliance. To address these issues, I implement an instrumental variable strategy. The proposed instrument is a measure of the arrival cost of labor inspectors to the firms. Labor inspectors travel by car from a local inspection agency in province $p$ to the firms to be inspected in the same province. The extension of the road network in each province provides a measure of the arrival cost to the firms. With a wider network, a higher geographic dispersion of firms is expected, increasing the arrival cost in terms of money and time. ${ }^{11}$ The arrival cost is also affected by the traffic in the road network in each province. A larger number of vehicles is expected to increase the cost. The instrumental variable is defined as follows:

$$
Z_{p s t}=\log \left(R N_{p t} * T_{p t}\right) * s h r_{s, 04}^{G V P} .
$$

The variable $R N_{p t}$ is the extension of the province road network (national plus provincial roads) in kilometers divided by the province territory. This variable differs greatly between provinces, but the variation over time is small. The variable $T_{p t}$ measures the traffic in the province road network as the number of per capita crossing vehicles in province $p$ and year $t$. The arrival cost is defined as the logarithm of the number of per capita crossing vehicles per kilometer of the ratio territory-province roads. In order to add variation at the sector level, I multiplied this measure by the share of each sector in the total gross production value in 2004. The reasoning is that labor inspections are focused on expansionary activities. Considering that a higher share of the gross production value is probably associated with a higher level of compliance, I predetermined the share using data of 2004.

One may argue that the extension of the province road network is capturing the level of development of each province, generating a violation to the exclusion restriction of the instrument. A wider road network eases the access to the main province markets, allowing cities which are further away from them to obtain products they would not have obtained otherwise. ${ }^{12}$ Thus, the key to the relationship between the extension of road networks and the development of the provinces is the distance separating remote locations from the main markets, i.e., the capital or other main cities. Given that the extension of road networks is essentially unchanged in my data, this effect will be captured by the province fixed effects. If some extension of the road network is implemented with the passing of time, I expect to capture its possible correlation with the development level through the inclusion of province-specific time trends and other controls for provinces' development level over time. A similar argument can be applied to the measure of traffic in province road networks.

Table 2 provides the first stage results for the samples of men and women and for different specifications. The measure of the arrival cost of labor inspectors is statistically significant in all specifications for the samples of men and women, and the estimates are remarkably stable across models. As expected, an increase in the measure of arrival cost reduces the degree of enforcement. Specifically, an increase 
Table 2 Arrival costs of labor inspectors and enforcement of labor regulations

\begin{tabular}{|c|c|c|c|c|c|c|}
\hline \multirow[t]{3}{*}{ Dependent variable } & \multicolumn{6}{|c|}{ Log(enforcement measure) } \\
\hline & \multicolumn{3}{|l|}{ Men } & \multicolumn{3}{|l|}{ Women } \\
\hline & $(1)$ & (2) & (3) & (4) & (5) & (6) \\
\hline \multirow[t]{2}{*}{ Log(arrival cost) ${ }^{*}$ shr04 } & -0.856 & -0.863 & -0.867 & -0.661 & -0.671 & -0.672 \\
\hline & {$[0.271]^{* * *}$} & {$[0.270]^{* * *}$} & {$[0.269]^{* * *}$} & {$[0.317]^{* *}$} & {$[0.314]^{* *}$} & {$[0.313]^{* *}$} \\
\hline Individual characteristics & Yes & Yes & Yes & Yes & Yes & Yes \\
\hline Political business cycle variables & Yes & Yes & Yes & Yes & Yes & Yes \\
\hline Quality of institutions variable & Yes & Yes & Yes & Yes & Yes & Yes \\
\hline Development level variables & No & Yes & Yes & No & Yes & Yes \\
\hline Demand shocks variables & No & Yes & Yes & No & Yes & Yes \\
\hline Province fixed effects & Yes & Yes & Yes & Yes & Yes & Yes \\
\hline Sector fixed effects & Yes & Yes & Yes & Yes & Yes & Yes \\
\hline Year fixed effects & Yes & Yes & Yes & Yes & Yes & Yes \\
\hline Province-time trends & No & No & Yes & No & No & Yes \\
\hline F statistic & 9.95 & 10.22 & 10.40 & 8.72 & 9.12 & 9.22 \\
\hline$p$ value of underid. test & 0.0016 & 0.0014 & 0.0012 & 0.01815 & 0.0161 & 0.0157 \\
\hline Observations & 148,166 & 148,166 & 148,166 & 83,906 & 83,906 & 83,906 \\
\hline$R^{2}$ & 0.686 & 0.688 & 0.697 & 0.715 & 0.721 & 0.732 \\
\hline
\end{tabular}

Source: Own elaboration. Notes: OLS estimations. Standard errors clustered at the province-sector level in brackets. Individual characteristics include age and age squared, indicators for educational level, marital status and size of the firm, and number of children at home. Political business cycle variables include logarithm of social per capita expenditure and primary result as a percentage of total incomes. Quality of institutions includes logarithm of absenteeism rate in provincial elections. Development level variables include logarithm of the population, logarithm of the per capita household income, and unsatisfied basic needs poverty indicator. Demand shocks includes logarithm of building permits per capita Significant at ${ }^{* *} 1 \%,{ }^{*} 5 \%$, and ${ }^{*} 10 \%$

of $1 \%$ in the arrival cost reduces the enforcement in around $0.86 \%$ for the sample of men and $0.67 \%$ for the sample of women. The Kleibergen-Paap F-statistic is above 10 for men in columns 2 and 3 and close to 10 for women, 10 being the rule of thumb for rejection of the hypothesis of having a weak instrument. The $p$ value of the underidentification test also allows the rejection of the hypothesis of having a weak instrument.

\section{Empirical results}

\subsection{Enforcement of labor regulations, compliance with mandated benefits and hourly} wages

Table 3 presents the results of the model of compliance with social security and employment regulations regressed on the enforcement measure using the most complete specification. Results are shown separately for the samples of men and women. Ordinary least squares (OLS) estimations are also provided.

Column 1 presents instrumental variables (IV) estimates of the effect of enforcement on the compliance with social security regulations (the wage employee receives contributions to the pension and health insurance systems). The impact is positive for men. A $10 \%$ increase in the enforcement effort in the province and sector where a male wage employee is located leads to an increase of 1 percentage point in the level of compliance. For the sample of women, the effect is negative and significant at a $10 \%$ level. The share of female wage employees receiving social 
Table 3 Enforcement of labor regulations and compliance with mandated benefits

\begin{tabular}{|c|c|c|c|c|}
\hline \multirow[t]{4}{*}{ Dependent variable } & \multicolumn{4}{|c|}{$=1$ if wage employee receives } \\
\hline & \multicolumn{2}{|c|}{ Social security benefits } & \multicolumn{2}{|c|}{ Employment benefits } \\
\hline & IV & OLS & IV & OLS \\
\hline & (1) & (2) & (3) & (4) \\
\hline \multicolumn{5}{|l|}{ Men } \\
\hline \multirow[t]{2}{*}{ Log(enforcement measure) } & 0.103 & 0.0103 & 0.0649 & 0.00578 \\
\hline & {$[0.0343]^{* * *}$} & [0.00968] & {$[0.0254]^{* *}$} & {$[0.00707]$} \\
\hline Observations & 148,166 & 148,166 & 148,166 & 148,166 \\
\hline$R^{2}$ & 0.277 & 0.286 & 0.164 & 0.168 \\
\hline \multicolumn{5}{|l|}{ Women } \\
\hline \multirow[t]{2}{*}{ Log(enforcement measure) } & -0.167 & -0.00486 & -0.138 & 0.00528 \\
\hline & {$[0.0963]^{*}$} & [0.0131] & {$[0.0784]^{*}$} & {$[0.0108]$} \\
\hline Observations & 83,906 & 83,906 & 83,906 & 83,906 \\
\hline$R^{2}$ & 0.218 & 0.253 & 0.210 & 0.233 \\
\hline \multicolumn{5}{|l|}{ Included controls } \\
\hline Individual characteristics & Yes & Yes & Yes & Yes \\
\hline Political business cycle variables & Yes & Yes & Yes & Yes \\
\hline Quality of institutions variable & Yes & Yes & Yes & Yes \\
\hline Development level variables & Yes & Yes & Yes & Yes \\
\hline Demand shocks variables & Yes & Yes & Yes & Yes \\
\hline Province fixed effects & Yes & Yes & Yes & Yes \\
\hline Sector fixed effects & Yes & Yes & Yes & Yes \\
\hline Year fixed effects & Yes & Yes & Yes & Yes \\
\hline Province-time trends & Yes & Yes & Yes & Yes \\
\hline
\end{tabular}

Source: Own elaboration. Notes: OLS and IV estimations. Standard errors clustered at the province-sector level in brackets. Control variables defined as in Table 2

Significant at $* * * 1 \%, * * \%$, and $* 10 \%$

security contributions at the province-sector level falls 1.7 percentage points for each $10 \%$ increase in enforcement. The effect of the enforcement measure on each social security benefit analyzed separately is provided in the Appendix and indicates an increase in the compliance with each of them among men, and a reduction among women (columns 1 and 2 of Appendix: Table 12).

Table 3 (column 3) shows the IV results when the dependent variable is the compliance with employment regulations (the wage employee receives paid vacations, annual extra monthly wage, paid sick days, earns at least the minimum wage, and works no more than the maximum of weekly hours). The effect is positive and statistically significant for men and indicates an increase of around 0.6 percentage points in the compliance with employment regulations for each $10 \%$ increase in enforcement. The effect for women is negative and significant at a $10 \%$ level. The magnitude indicates a reduction of 1.4 percentage points in the share of female wage earners receiving all employment benefits at the province-sector level for each $10 \%$ increase in enforcement. The impact on each employment benefit analyzed separately shows an increase in the share of men and a reduction in the share of women receiving each of them, except for the not significant change in the maximum of weekly hours of work for men (columns 3 to 7 of Appendix: Table 12). 
The sign of OLS bias is not clear in theory. On the one hand, enforcement can be stricter in more developed provinces, where the level of compliance is also higher (positive bias). On the other hand, lobby groups may negotiate lower enforcement levels by showing high compliance rates (negative bias). OLS estimations in columns 2 and 4 of Table 3 are smaller (in absolute value) compared to IV estimates, suggesting the presence of a negative bias for men and a positive bias for women. However, OLS estimates are not statistically significant in any case.

The negative impacts of a higher level of enforcement on the share of female wage employees that in each province-sector combination receives mandated benefits are statistically weak but suggest a reallocation of women to informal firms, probably after being laid-off from formal firms. ${ }^{13}$ These findings are in line with women having a low valuation of some mandated benefits, especially the health insurance, which they can obtain through other members of their family. Table 4 provides suggestive evidence in favor of this argument by splitting the sample according to marital status. Results indicate that when enforcement increases, the share of men receiving mandated benefits improves regardless their marital status (although the magnitudes of the impacts are larger among married men). Among women, the negative effects of a higher degree of enforcement appear only for married women. Despite this suggestive evidence, the movement to informal firms as a last resort option cannot be ruled out.

How can these findings be interpreted in light of the theoretical discussion of Section 4? To help to interpret the results on the level of compliance, Table 5 provides additional evidence on the impact of enforcement on hourly wages and percentiles of the wage distribution. The sample is split according to the formality status of workers: wage employees receiving mandated benefits are formal workers, while wage earners not receiving them are informal workers. Results indicate that enforcement increases have a positive impact on average formal wages for men (an increase of about $0.5 \%$ for each $10 \%$ increase in enforcement) and no impact on average informal wages. For women, a higher level of enforcement reduces hourly wages of informal workers (reduction of $2.5 \%$ for each $10 \%$ increase in enforcement) with no effect on average formal wages.

Columns $2-4$ and $6-8$ of Table 5 show the results obtained when the response variables are the 10th percentile of the distribution of the logarithm of formal and informal hourly wages in each province-sector, the 50th percentile and the 90th percentile respectively. Results show that formal hourly wages increase along the entire wage distribution for men, while there is a reduction at the 50th and 90th percentiles of the informal wage distribution. Among women, there is a reduction of informal hourly wages in the middle of the distribution and no changes of formal hourly wages.

All these findings are consistent with the theoretical discussion of Section 4 . When faced with an increase in enforcement, formal firms start complying with the rules they were evading (substitution effect). Firms increase the demand for formal employees (workers receiving mandated benefits) and reduce the demand for informal employees (workers with no benefits). The corresponding adjustment in wages is an increase in formal wages and a reduction in informal wages. An increase in formal wages at the bottom of the wage distribution is also expected 
Table 4 Enforcement of labor regulations and compliance with mandated benefits by marital status

\begin{tabular}{|c|c|c|c|c|}
\hline \multirow[t]{4}{*}{ Dependent variable } & \multicolumn{4}{|c|}{$=1$ if wage employee receives } \\
\hline & \multicolumn{2}{|c|}{ Social security benefits } & \multicolumn{2}{|c|}{ Employment benefits } \\
\hline & Married & Unmarried & Married & Unmarried \\
\hline & (1) & (2) & (3) & (4) \\
\hline \multicolumn{5}{|l|}{ Men } \\
\hline \multirow[t]{2}{*}{ Log(enforcement measure) } & 0.125 & 0.0565 & 0.0631 & 0.0620 \\
\hline & {$[0.0388]^{* * *}$} & {$[0.0246]^{* *}$} & {$[0.0226]^{* * *}$} & {$[0.0303]^{* *}$} \\
\hline Observations & 93,037 & 55,129 & 93,037 & 55,129 \\
\hline$R^{2}$ & 0.230 & 0.305 & 0.146 & 0.199 \\
\hline \multicolumn{5}{|l|}{ Women } \\
\hline \multirow[t]{2}{*}{ Log(enforcement measure) } & -0.227 & -0.139 & -0.190 & -0.117 \\
\hline & {$[0.126]^{*}$} & {$[0.0987]$} & {$[0.104]^{*}$} & {$[0.0804]$} \\
\hline Observations & 42,278 & 41,628 & 42,278 & 41,628 \\
\hline$R^{2}$ & 0.183 & 0.232 & 0.188 & 0.203 \\
\hline \multicolumn{5}{|l|}{ Included controls } \\
\hline Individual characteristics & Yes & Yes & Yes & Yes \\
\hline Political business cycle variables & Yes & Yes & Yes & Yes \\
\hline Quality of institutions variable & Yes & Yes & Yes & Yes \\
\hline Development level variables & Yes & Yes & Yes & Yes \\
\hline Demand shocks variables & Yes & Yes & Yes & Yes \\
\hline Province fixed effects & Yes & Yes & Yes & Yes \\
\hline Sector fixed effects & Yes & Yes & Yes & Yes \\
\hline Year fixed effects & Yes & Yes & Yes & Yes \\
\hline Province-time trends & Yes & Yes & Yes & Yes \\
\hline
\end{tabular}

Source: Own elaboration. Notes: IV estimations. Standard errors clustered at the province-sector level in brackets. Control variables defined as in Table 2

Significant at ${ }^{* *} 1 \%, * * 5 \%$, and ${ }^{*} 10 \%$

if the compliance with the minimum wage regulation increases. All these adjustments are supported by the empirical findings for men, but they are at odds with the findings for women. Among women, the effect of the reduction in the size of the labor force (scale effect) offsets any substitution of formal wage employees for informal wage employees. Some women are laid-off and the movement to an informal firm of those who were receiving mandated benefits explains the increase in informal employment (reduction in the share of women receiving mandated benefits), the reduction in formal wages (although not significant) and the reduction in informal wages. All these empirical findings can also be interpreted in light of models with labor market frictions, such as efficiency wages and search models, where labor demand increases lead to increases in wages even when there is unemployment (Albrecht et al. 2009; Meghir et al. 2015).

What explains the heterogenous adjustment across gender? Once I control for educational level and other individual characteristics, the difference between formal and informal wage employees, men or women, is the compliance with labor regulations. Labor regulations are such that formal and informal men have a higher 
Table 5 Enforcement of labor regulations and logarithm of hourly wages and percentiles of the distribution of the logarithm of hourly wages

\begin{tabular}{|c|c|c|c|c|c|c|c|c|}
\hline \multirow[t]{3}{*}{ Dependent variable } & \multicolumn{4}{|c|}{ Formal wage employees } & \multicolumn{4}{|c|}{ Informal wage employees } \\
\hline & Average & 10th & 50th & 90th & Average & 10th & 50th & 90th \\
\hline & (1) & (2) & (3) & (4) & (5) & (6) & (7) & (8) \\
\hline \multicolumn{9}{|l|}{ Men } \\
\hline \multirow{2}{*}{$\begin{array}{l}\text { Log(enforcement } \\
\text { measure) }\end{array}$} & 0.0465 & 0.0279 & 0.0126 & 0.0300 & -0.0385 & -0.0163 & -0.0282 & -0.0315 \\
\hline & {$[0.0218]^{* *}$} & {$[0.0102]^{* * *}$} & {$[0.00623]^{* *}$} & {$[0.0117]^{* *}$} & {$[0.0461]$} & {$[0.0131]$} & {$[0.0150]^{*}$} & {$[0.0118]^{* * *}$} \\
\hline Observations & 91,231 & 91,231 & 91,231 & 91,231 & 56,935 & 56,935 & 56,935 & 56,935 \\
\hline$R^{2}$ & 0.302 & 0.718 & 0.864 & 0.768 & 0.229 & 0.810 & 0.858 & 0.820 \\
\hline \multicolumn{9}{|l|}{ Women } \\
\hline \multirow{2}{*}{$\begin{array}{l}\text { Log(enforcement } \\
\text { measure) }\end{array}$} & -0.0844 & -0.146 & -0.115 & -0.149 & -0.252 & -0.249 & -0.175 & -0.296 \\
\hline & {$[0.0927]$} & {$[0.126]$} & {$[0.134]$} & {$[0.172]$} & {$[0.120]^{* *}$} & {$[0.181]$} & {$[0.0842]^{* *}$} & {$[0.184]$} \\
\hline Observations & 59,919 & 59,919 & 59,919 & 59,919 & 23,987 & 23,987 & 23,987 & 23,987 \\
\hline$R^{2}$ & 0.341 & 0.650 & 0.835 & 0.685 & 0.220 & 0.773 & 0.809 & 0.692 \\
\hline \multicolumn{9}{|l|}{ Included controls: } \\
\hline $\begin{array}{l}\text { Individual } \\
\text { characteristics }\end{array}$ & Yes & Yes & Yes & Yes & Yes & Yes & Yes & Yes \\
\hline $\begin{array}{l}\text { Political business } \\
\text { cycle variables }\end{array}$ & Yes & Yes & Yes & Yes & Yes & Yes & Yes & Yes \\
\hline $\begin{array}{l}\text { Quality of institutions } \\
\text { variable }\end{array}$ & Yes & Yes & Yes & Yes & Yes & Yes & Yes & Yes \\
\hline $\begin{array}{l}\text { Development level } \\
\text { variables }\end{array}$ & Yes & Yes & Yes & Yes & Yes & Yes & Yes & Yes \\
\hline $\begin{array}{l}\text { Demand shocks } \\
\text { variables }\end{array}$ & Yes & Yes & Yes & Yes & Yes & Yes & Yes & Yes \\
\hline Province fixed effects & Yes & Yes & Yes & Yes & Yes & Yes & Yes & Yes \\
\hline Sector fixed effects & Yes & Yes & Yes & Yes & Yes & Yes & Yes & Yes \\
\hline Year fixed effects & Yes & Yes & Yes & Yes & Yes & Yes & Yes & Yes \\
\hline Province-time trends & Yes & Yes & Yes & Yes & Yes & Yes & Yes & Yes \\
\hline
\end{tabular}

Source: Own elaboration. Notes: IV estimations. Standard errors clustered at the province-sector level in brackets. Control variables defined as in Table 2

Significant at ${ }^{* *} 1 \%$, $*$ * $5 \%$, and ${ }^{*} 10 \%$

degree of substitutability in the production process than formal and informal women. For instance, formal women enjoy a maternity leave and probably make more use of leaves for illness of a family member in comparison to informal women (and in comparison to men). Given these rules, it is less convenient for firms to substitute informal women with formal women than doing it among men.

\subsection{Enforcement of labor regulations, non-mandated benefits and composition of employment}

According to the theoretical discussion in Section 4, firms can look for an additional adjustment mechanism to compensate for the increased labor costs as a result of the higher level of enforcement. Table 6 presents the results obtained when the outcome variable is the provision of non-mandated benefits, such as meals at work, housing, or products. Findings indicate that for both men and women, the impact of a higher level 
Table 6 Enforcement of labor regulations and provision of non-mandated benefits

\begin{tabular}{|c|c|c|c|}
\hline \multirow[t]{3}{*}{ Dependent variable } & \multicolumn{3}{|c|}{$=1$ if wage employee receives } \\
\hline & Free meals & Housing & Products \\
\hline & (1) & (2) & (3) \\
\hline \multicolumn{4}{|l|}{ Men } \\
\hline \multirow[t]{2}{*}{ Log(enforcement measure) } & -0.00140 & 0.0328 & -0.00295 \\
\hline & [0.0193] & {$[0.0237]$} & {$[0.00465]$} \\
\hline Observations & 148,166 & 148,166 & 148,166 \\
\hline$R^{2}$ & 0.122 & 0.045 & 0.018 \\
\hline \multicolumn{4}{|l|}{ Women } \\
\hline \multirow[t]{2}{*}{ Log(enforcement measure) } & 0.0178 & 0.00616 & -0.000505 \\
\hline & {$[0.0298]$} & {$[0.00425]$} & {$[0.0101]$} \\
\hline Observations & 83,906 & 83,906 & 83,906 \\
\hline$R^{2}$ & 0.141 & 0.010 & 0.027 \\
\hline \multicolumn{4}{|l|}{ Included controls } \\
\hline Individual characteristics & Yes & Yes & Yes \\
\hline Political business cycle variables & Yes & Yes & Yes \\
\hline Quality of institutions variable & Yes & Yes & Yes \\
\hline Development level variables & Yes & Yes & Yes \\
\hline Demand shocks variables & Yes & Yes & Yes \\
\hline Province fixed effects & Yes & Yes & Yes \\
\hline Sector fixed effects & Yes & Yes & Yes \\
\hline Year fixed effects & Yes & Yes & Yes \\
\hline Province-time trends & Yes & Yes & Yes \\
\hline
\end{tabular}

Source: Own elaboration. Notes: IV estimations. Standard errors clustered at the province-sector level in brackets. Control variables defined as in Table 2

Significant at ${ }^{* *} 1 \%, * * 5 \%$, and ${ }^{*} 10 \%$

of enforcement is very small in magnitude and not significant statistically in any of the estimated models.

In Table 7, I analyze how the changes in the enforcement level across provinces, sectors, and over time impact the composition of employment between wage employment and self-employment. ${ }^{14}$ For the sample of men, column 1 shows that increases in enforcement lead to increases in the share of wage employment in relation to self-employment. When separating wage employment in formal and informal (columns 2 and 3), the findings reveal an increase in the shares of formal and informal wage employment in detriment of self-employment among men. One important question to interpret these findings is who the self-employed are. They could be persons working at the bottom of the job structure, hoping to get out of that employment category where entry is not restricted and earnings are low, or they could belong to a restricted-entry category where a stock of financial and/or human capital is needed to enter and where earnings are high (Fields 2005). The comparison of the educational level and earnings of self-employed workers, formal and informal wage employees indicate that self-employed are similar to informal wage earners. ${ }^{15}$ Self-employment seems to be a non-desired employment category among men. The findings indicate that self-employed men are attracted 
Table 7 Enforcement of labor regulations and employment composition

\begin{tabular}{|c|c|c|c|}
\hline \multirow[t]{3}{*}{ Dependent variable } & \multicolumn{3}{|l|}{$=1$ if workers is } \\
\hline & Wage employee & Formal wage employee & Informal wage employee \\
\hline & (1) & (2) & (3) \\
\hline \multicolumn{4}{|l|}{ Men } \\
\hline \multirow[t]{2}{*}{ Log(enforcement measure) } & 0.0469 & 0.0646 & 0.0487 \\
\hline & {$[0.0242]^{*}$} & {$[0.0312]^{* *}$} & {$[0.0271]^{*}$} \\
\hline Observations & 202,277 & 143,956 & 109,831 \\
\hline$R^{2}$ & 0.457 & 0.725 & 0.423 \\
\hline \multicolumn{4}{|l|}{ Women } \\
\hline \multirow[t]{2}{*}{ Log(enforcement measure) } & 0.0415 & -0.0303 & 0.162 \\
\hline & {$[0.0280]$} & {$[0.0391]$} & {$[0.0678]^{* *}$} \\
\hline Observations & 109,461 & 84,702 & 48,832 \\
\hline$R^{2}$ & 0.472 & 0.694 & 0.442 \\
\hline \multicolumn{4}{|l|}{ Included controls: } \\
\hline Individual characteristics & Yes & Yes & Yes \\
\hline Political business cycle variables & Yes & Yes & Yes \\
\hline Quality of institutions variable & Yes & Yes & Yes \\
\hline Development level variables & Yes & Yes & Yes \\
\hline Demand shocks variables & Yes & Yes & Yes \\
\hline Province fixed effects & Yes & Yes & Yes \\
\hline Sector fixed effects & Yes & Yes & Yes \\
\hline Year fixed effects & Yes & Yes & Yes \\
\hline Province-time trends & Yes & Yes & Yes \\
\hline
\end{tabular}

Source: Own elaboration. Notes: IV estimations. Omitted category: self-employment. Standard errors clustered at the province-sector level in brackets. Control variables defined as in Table 2

Significant at ${ }^{* * *} 1 \%, * * 5 \%$, and ${ }^{*} 10 \%$

by the higher chances of obtaining mandated benefits when working as wage employees and change their employment category. The increased labor supply in the formal sector should reduce hourly formal wages for men, but the increased demand due to the substitution effect seems to be offsetting that impact. When the higher demand for formal wage employees is satisfied, those self-employed who could not get a formal job obtain a position as wage employees in an informal firm, providing an additional explanation for the reduction in informal wages for men.

For the sample of women, there is no significant impact of the enforcement measure on the chances of being a formal wage employee with respect to being a self-employed worker (column 2 of Table 7). This evidence indicates that women who were receiving mandated benefits and lose their jobs do not switch to self-employment, i.e., they move to informal firms where they continue being wage employees but without mandated benefits. Results also show an increase in the probability of informal wage employment with respect to self-employment (column 3 of Table 7). Self-employed women try to obtain a job as wage employees when enforcement increases, even when the impact on women is a reduction in the coverage of mandated benefits. This result can be interpreted as the expectation of obtaining a formal position in the 
Table 8 Relocation decisions of firms

\begin{tabular}{|c|c|c|c|c|c|c|c|}
\hline \multirow[t]{3}{*}{ Dependent variable } & \multirow{2}{*}{$\begin{array}{l}=1 \text { if } \\
\text { social sec. } \\
\text { benefits }\end{array}$} & \multirow{2}{*}{$\begin{array}{l}=1 \text { if } \\
\text { emp. } \\
\text { benefits }\end{array}$} & \multirow{2}{*}{$\begin{array}{l}\text { Log of } \\
\text { hourly } \\
\text { formal wages }\end{array}$} & \multirow{2}{*}{$\begin{array}{l}\text { Log of } \\
\text { hourly } \\
\text { informal } \\
\text { wages }\end{array}$} & \multicolumn{3}{|c|}{$=1$ if worker is } \\
\hline & & & & & \multirow{2}{*}{$\begin{array}{l}\text { Wage } \\
\text { employee } \\
\text { (7) }\end{array}$} & \multirow{2}{*}{$\begin{array}{l}\text { Formal wage } \\
\text { employee } \\
\text { (8) }\end{array}$} & \multirow{2}{*}{$\begin{array}{l}\text { Informal wage } \\
\text { employee } \\
\text { (9) }\end{array}$} \\
\hline & (1) & (2) & (3) & (4) & & & \\
\hline \multicolumn{8}{|l|}{ Men } \\
\hline \multirow{2}{*}{$\begin{array}{l}\text { Log(enforcement } \\
\text { measure) }\end{array}$} & 0.103 & 0.0649 & 0.0465 & -0.0388 & 0.0470 & 0.0647 & 0.0488 \\
\hline & {$[0.0342]^{* * *}$} & {$[0.0254]^{* *}$} & {$[0.0211]^{* *}$} & {$[0.0466]$} & {$[0.0242]^{*}$} & {$[0.0313]^{* *}$} & {$[0.0271]^{*}$} \\
\hline Observations & 148,166 & 148,166 & 91,231 & 56,935 & 202,277 & 143,956 & 109,831 \\
\hline$R^{2}$ & 0.277 & 0.164 & 0.302 & 0.229 & 0.457 & 0.725 & 0.423 \\
\hline \multicolumn{8}{|l|}{ Women } \\
\hline \multirow{2}{*}{$\begin{array}{l}\text { Log(enforcement } \\
\text { measure) }\end{array}$} & -0.165 & -0.138 & -0.0841 & -0.256 & 0.0384 & -0.0310 & 0.178 \\
\hline & {$[0.0950]^{*}$} & {$[0.0778]^{*}$} & {$[0.0870]$} & {$[0.122]^{* *}$} & {$[0.0260]$} & {$[0.0396]$} & {$[0.0756]^{* *}$} \\
\hline Observations & 83,906 & 83,906 & 59,919 & 23,987 & 109,461 & 84,702 & 48,832 \\
\hline$R^{2}$ & 0.224 & 0.212 & 0.337 & 0.217 & 0.470 & 0.693 & 0.434 \\
\hline \multicolumn{8}{|l|}{ Included controls } \\
\hline $\begin{array}{l}\text { Individual } \\
\text { characteristics }\end{array}$ & Yes & Yes & Yes & Yes & Yes & Yes & Yes \\
\hline $\begin{array}{l}\text { Political business } \\
\text { cycle variables }\end{array}$ & Yes & Yes & Yes & Yes & Yes & Yes & Yes \\
\hline $\begin{array}{l}\text { Quality of } \\
\text { institutions } \\
\text { variable }\end{array}$ & Yes & Yes & Yes & Yes & Yes & Yes & Yes \\
\hline $\begin{array}{l}\text { Development } \\
\text { level variables }\end{array}$ & Yes & Yes & Yes & Yes & Yes & Yes & Yes \\
\hline $\begin{array}{l}\text { Demand shocks } \\
\text { variables }\end{array}$ & Yes & Yes & Yes & Yes & Yes & Yes & Yes \\
\hline Oil prices & Yes & Yes & Yes & Yes & Yes & Yes & Yes \\
\hline $\begin{array}{l}\text { Province fixed } \\
\text { effects }\end{array}$ & Yes & Yes & Yes & Yes & Yes & Yes & Yes \\
\hline $\begin{array}{l}\text { Sector fixed } \\
\text { effects }\end{array}$ & Yes & Yes & Yes & Yes & Yes & Yes & Yes \\
\hline Year fixed effects & Yes & Yes & Yes & Yes & Yes & Yes & Yes \\
\hline $\begin{array}{l}\text { Province-time } \\
\text { trends }\end{array}$ & Yes & Yes & Yes & Yes & Yes & Yes & Yes \\
\hline
\end{tabular}

Source: Own elaboration. Notes: IV estimations. Omitted category in columns 7-9: self-employment. Standard errors clustered at the province-sector level in brackets. Control variables defined as in Table 2

Significant at ${ }^{* *} 1 \%$, $* * 5$, and ${ }^{*} 10 \%$

future. Because formal firms' demand is falling both for formal and informal female wage employees (scale effect), self-employed women switch to wage employment in informal firms.

\section{Additional estimations}

\subsection{Relocation decisions of firms}

A firm may decide to relocate when the share of inspected firms is increasing in its province-sector. One determinant of firms' location decisions is the distance to the main product and intermediate product markets which are probably located in the capital or some other main cities. These are the cities where the local inspection agencies 
Table 9 Number of labor inspection agencies in each province

\begin{tabular}{|c|c|c|c|c|c|c|c|}
\hline \multirow[t]{3}{*}{ Dependent variable } & \multirow{2}{*}{$\begin{array}{l}=1 \text { if } \\
\text { social } \\
\text { benefits }\end{array}$} & \multirow{2}{*}{$\begin{array}{l}=1 \text { if } \\
\text { emp. } \\
\text { benefits }\end{array}$} & \multirow{2}{*}{$\begin{array}{l}\text { Log of } \\
\text { hourly } \\
\text { formal } \\
\text { wages }\end{array}$} & \multirow{2}{*}{$\begin{array}{l}\text { Log of } \\
\text { hourly } \\
\text { informal } \\
\text { wages }\end{array}$} & \multicolumn{3}{|c|}{$=1$ if worker is } \\
\hline & & & & & \multirow{2}{*}{$\begin{array}{l}\text { Wage } \\
\text { employee } \\
\text { (7) }\end{array}$} & \multirow{2}{*}{$\begin{array}{l}\text { Formal wage } \\
\text { employee } \\
\text { (8) }\end{array}$} & \multirow{2}{*}{$\begin{array}{l}\text { Informal wage } \\
\text { employee } \\
\text { (9) }\end{array}$} \\
\hline & (1) & (2) & (3) & (4) & & & \\
\hline \multicolumn{8}{|l|}{ Men } \\
\hline \multirow{2}{*}{$\begin{array}{l}\text { Log(enforcement } \\
\text { measure) }\end{array}$} & 0.107 & 0.0704 & 0.0437 & -0.0356 & 0.0529 & 0.0675 & 0.0573 \\
\hline & {$[0.0362]^{* * *}$} & {$[0.0267]^{* * *}$} & {$[0.0224]^{*}$} & {$[0.0441]$} & {$[0.0261]^{* *}$} & {$[0.0321]^{* *}$} & {$[0.0297]^{*}$} \\
\hline Observations & 148,166 & 148,166 & 91,231 & 56,935 & 202,277 & 143,956 & 109,831 \\
\hline$R^{2}$ & 0.276 & 0.163 & 0.302 & 0.229 & 0.456 & 0.725 & 0.422 \\
\hline \multicolumn{8}{|l|}{ Women } \\
\hline \multirow{2}{*}{$\begin{array}{l}\text { Log(enforcement } \\
\text { measure) }\end{array}$} & -0.146 & -0.118 & -0.0615 & -0.264 & 0.0527 & -0.0148 & 0.186 \\
\hline & {$[0.0748]^{*}$} & {$[0.0603]^{*}$} & {$[0.0654]$} & {$[0.121]^{* *}$} & {$[0.0282]^{*}$} & [0.0289] & {$[0.0745]^{* *}$} \\
\hline Observations & 83,906 & 83,906 & 59,919 & 23,987 & 109,461 & 84,702 & 48,832 \\
\hline$R^{2}$ & 0.231 & 0.219 & 0.340 & 0.216 & 0.469 & 0.694 & 0.433 \\
\hline \multicolumn{8}{|l|}{ Included controls: } \\
\hline $\begin{array}{l}\text { Individual } \\
\text { characteristics }\end{array}$ & Yes & Yes & Yes & Yes & Yes & Yes & Yes \\
\hline $\begin{array}{l}\text { Political business cycle } \\
\text { variables }\end{array}$ & Yes & Yes & Yes & Yes & Yes & Yes & Yes \\
\hline $\begin{array}{l}\text { Quality of institutions } \\
\text { variable }\end{array}$ & Yes & Yes & Yes & Yes & Yes & Yes & Yes \\
\hline $\begin{array}{l}\text { Development level } \\
\text { variables }\end{array}$ & Yes & Yes & Yes & Yes & Yes & Yes & Yes \\
\hline $\begin{array}{l}\text { Demand shocks } \\
\text { variables }\end{array}$ & Yes & Yes & Yes & Yes & Yes & Yes & Yes \\
\hline Province fixed effects & Yes & Yes & Yes & Yes & Yes & Yes & Yes \\
\hline Sector fixed effects & Yes & Yes & Yes & Yes & Yes & Yes & Yes \\
\hline Year fixed effects & Yes & Yes & Yes & Yes & Yes & Yes & Yes \\
\hline Province-time trends & Yes & Yes & Yes & Yes & Yes & Yes & Yes \\
\hline
\end{tabular}

Source: Own elaboration. Notes: IV estimations. Omitted category in columns 7-9: self-employment. Standard errors clustered at the province-sector level in brackets. Control variables defined as in Table 2

Significant at ${ }^{* *} 1 \%$, **5\%, and ${ }^{*} 10 \%$

are located in each province. If a firm decides to move further away from the inspection agencies, it will imply to move away from the main markets too. To control for this determinant of firms' location decisions, I include a measure of transportation costs at the province level: retail oil price for each province and year. ${ }^{16}$ IV estimations are shown in Tables 8 while first-stage results are provided in Table 13 in the Appendix. Results for both men and women are in line with previous estimates.

\subsection{Number of labor inspection agencies in each province}

One may worry that the measure of the arrival cost of labor inspectors to the firms (instrumental variable) is overestimated in provinces having more than one local inspection agency. To capture this possibility, I redefine the instrumental variable dividing $R N_{p t}{ }^{*} T_{p t}$ by the number of local inspection agencies in each province. 
Table 10 Composition of employment by economic sector

\begin{tabular}{lll}
\hline Dependent variable & $=1$ if social sec. benefits & $=1$ if emp. benefits \\
& $(1)$ & $(2)$ \\
\hline Women & -0.120 & -0.117 \\
Log(enforcement measure) & {$[0.0405]^{* * *}$} & {$[0.0345]^{* * *}$} \\
& 83,906 & 83,906 \\
Observations & 0.237 & 0.207 \\
$R^{2}$ & & \\
Included controls & Yes & Yes \\
Individual characteristics & Yes & Yes \\
Political business cycle variables & Yes & Yes \\
Quality of institutions variable & Yes & Yes \\
Development level variables & Yes & Yes \\
Demand shocks variables & Yes & Yes \\
Province fixed effects & Yes & Yes \\
Sector fixed effects & Yes & Yes \\
Year fixed effects & Yes & Yes \\
Province-time trends & Tes &
\end{tabular}

Source: Own elaboration. Notes: IV estimations. Omitted category in columns 7-9: self-employment. Standard errors clustered at the province-sector level in brackets. Control variables defined as in Table 2

Significant at ${ }^{* *} 1 \%, * * 5 \%$, and ${ }^{*} 10 \%$

Results are presented in Table 9 and are in line with previous findings for men and women.

\subsection{Composition of employment by economic sector}

The heterogenous results for men and women may be reflecting the differential impact of labor regulations on the substitutability of formal and informal workers and also the fact that men and women are employed in different sectors. In order to check for this possibility, I re-weighted the sample of women to have the same distribution of employment by sector as the sample of men in each year. Results in Table 10 show that the reduction in the share of women receiving mandated benefits is still present using the re-weighted sample.

\section{Conclusions}

In this paper, I explored how changes in the enforcement of labor regulations in Argentina affect different labor market indicators among men and women. Labor regulations are extensive in this country, but enforcement is imperfect, generating incentives to the firms for not complying with the labor rules.

Taking advantage of the highly decentralized labor inspection system in Argentina, I constructed an enforcement measure (logarithm of the number of inspected firms per hundred formal firms) with variation at the province, sector, and time level. The econometric strategy linked indicators of compliance with labor regulations and other labor outcomes with the enforcement measure and with a rich set of individual characteristics, and economic, institutional and development characteristics of Argentine 
provinces. To deal with the possible endogeneity of the enforcement measure in this setting, I instrumented it using a measure of the arrival cost of labor inspectors to the firms.

The findings revealed heterogenous effects of an increase in enforcement at the province-sector level on compliance and other labor outcomes among men and women. Higher enforcement leads firms to substitute formal wage employees for informal wage employees among men. Formal wages increase, informal wages decline, and self-employed men become wage earners to take advantage of the increase in the provision of mandated benefits-although the increase in labor supply in the formal sector is not enough to compensate for the increase in demand resulting in an increase in formal wages. Among women, there is a reduction in the demand for both formal and informal wage employees, and a decline in formal and informal wages (although not significant for formal wages). Laid-off women move to informal firms where they obtain a job without mandated benefits. Some self-employed women become informal wage employees, probably attracted by the probability of obtaining better employment conditions in the future. The heterogenous impacts of a higher level of enforcement are explained by labor regulations which vary by gender in some cases, e.g., maternity leave, or have a different impact on firms' costs due to different men and women characteristics, e.g., contributions to the pension system which are a function of monthly labor earnings. Labor regulations make formal and informal men more substitutable in the production process than formal and informal women.

A general pattern of higher compliance with labor regulation as a result of higher enforcement (with no distinction between men and women) was also reported by Ronconi (2010) for Argentina and Almeida and Carneiro (2012) and Almeida et al. (2013) for Brazil. Almeida and Carneiro (2012) also report a decline in informal employment and a reduction in formal wages that the authors interpret as a price formal workers pay for more generous benefits. In terms of the theoretical mechanisms discussed in this paper, the increase in formal employment and reduction in informal employment would be explained by a substitution effect that offsets the scale effect, and the reduction in formal wages would be the result of self-employed workers looking for formal wage jobs which are now more attractive.

These empirical findings have important policy implications in terms of gender equality in the labor market. A higher degree of enforcement improves male working conditions but has the unintended effect of driving women into the informal sector of the economy. This type of leakages should be considered when designing labor regulations and deciding about labor inspections to avoid offsetting the intended effect of labor rules and the labor inspection system, i.e., to increase the share of all workers receiving labor benefits.

\section{Endnotes}

${ }^{1}$ The labor inspection system introduced by the law is also known as National Plan of Labor Regularization which was active during the period analyzed in this paper.

${ }^{2}$ I will consider CABA as an additional province throughout the study. 
${ }^{3}$ Buenos Aires province has 10 local inspection agencies, Río Negro has three, Chubut, Entre Ríos, Mendoza, Santa Cruz, and Santa Fe have two, while the remaining 17 provinces have one local inspection agency. The number of local inspection agencies did not change during the period covered in this study.

${ }^{4}$ According to the functioning of the labor inspection system in Argentina, a firm is formal (and it is a target of labor inspections) if it has declared at least one employee in the registration system.

${ }^{5}$ Severance pay in Argentina is calculated as one monthly earning per year of tenure in the firm considering the best monthly earning received.

${ }^{6}$ The Argentine household survey contains information on whether wage employees receive mandated benefits or not. Wage employees receiving benefits are employed in formal firms. Wage employees not receiving mandated benefits can be employed in a formal or an informal firm.

${ }^{7}$ Because the probability of detection usually increases with the size of a firm (Almeida and Ronconi 2016), firms may also want to reduce the number of employees as a way to reduce the chances of being inspected.

${ }^{8}$ Labor regulations in Argentina allow the payment of up to $20 \%$ of monthly earnings in products, food or housing. Social security contributions have to be calculated both on in-kind and in-cash payments.

${ }^{9}$ This pattern differs from results presented in Fig. 1. The difference is explained by the exclusion of public sector employees and domestic service workers from the sample used in this section.

${ }^{10}$ The questionnaire allows me to identify persons who work in a different province from where they live. With this information, I reassigned these people to the province where they work, so they can be affected by the enforcement level of that province.

${ }^{11}$ Local inspection agencies are based in the main cities of each province (e.g., capital city) where a large share of firms is probably located. A measure of the geographic dispersion of firms in each province's territory would improve the instrument as an arrival cost measure. However, the lack of that information does not affect the validity of the instrument.

${ }^{12}$ Roads are the main option to connect geographic points in Argentina. Railroads are not widespread.

${ }^{13}$ Exit from the labor force could be another margin of adjustment. The variation of the enforcement data at the sector level does not allow me to link people out of the labor force with the enforcement measure.

${ }^{14}$ The average percentage of self-employed workers over the entire period was $14.3 \%$ for women and $20.1 \%$ for men.

${ }^{15}$ The average years of education for formal and informal wage employees is 11.5 and 9.6 respectively, and for self-employed workers is 10.1 . The average monthly earnings are $\$ 1291$ for formal wage employees, $\$ 669$ for informal wage employees, and $\$ 830$ for self-employed workers.

${ }^{16}$ The location decisions of firms would be better captured by characteristics of the cities where firms are located within each province. However, this level of geographical detail (city where the worker is employed) is not available in Argentine household surveys. 


\section{Appendix}

Table 11 Variables definition and sources of data

\begin{tabular}{ll}
\hline Variables & Definition \\
\hline Social security regulations & $\begin{array}{l}\text { Indicator variable for whether the worker receives contributions to the pension } \\
\text { system and the health insurance system. Source: Encuesta Permanente de } \\
\text { Hogares. }\end{array}$
\end{tabular}

Employment regulations Indicator variable for whether the worker receives paid vacations, annual extra monthly wage, paid sick days, earns the minimum wage or more, and works no more than the legislated maximum of weekly hours. Source: Encuesta Permanente de Hogares.

Non-mandated benefits

Set of three indicator variables for whether the worker receives meals at work, receives housing, or receives free products. Source: Encuesta Permanente de Hogares.

Hourly wage and monthly labor income

Hourly wage and monthly labor income in main occupation in local currency

Percentiles of the wage distribution at 2005 prices. Source: Encuesta Permanente de Hogares.

10th, 50th and 90th percentiles of the distribution of the logarithm of hourly wages calculated at the province, sector, and year level. Source: Encuesta Permanente de Hogares.

Employment categories

Set of two indicator variables for whether the worker is a salaried employee or is selfemployed. Source: Encuesta Permanente de Hogares.

Enforcement measure

Logarithm of the ratio between the number of inspected firms and the total number of formal firms in each province, sector and year. Source: MTEySS.

Arrival cost of labor inspectors

Logarithm of extension of the road network in each province and year multiplied by the number of crossing vehicles in each province and year. The road network is normalized by the territory of each province and the number of crossing vehicles is expressed in a per capita basis. The logarithm is multiplied by the share of each sector in the total gross production value in 2004. Sources: INDEC, Consejo Vial Federal, and Asociación Argentina de Carreteras.

Educational levels

Skilled workers: complete college education; Semi-skilled: complete secondary education or incomplete college education; Unskilled: incomplete secondary education or lower.

Firm size

Small size: 5 employees or less; Medium size: 6 to 40 employees; Large size: 41 employees or more.

Economic sectors

$1=$ Agriculture, animal production, hunting, forestry, and fishing; $2=$ Mining and quarrying; 3 = Manufacturing; 4 = Electricity, gas and water supply; $5=$ Construction; $6=$ Wholesale and retail trade, and real estate activities; $7=$ Accommodation and food service activities; $8=$ Transportation and storage, communication, and financial intermediation; $9=$ Education; $10=$ Human health and social work activities, and personal services.

Social expenditure

Logarithm of social expenditure expressed in a per capita basis at 2005 prices for each province and year. Source: Dirección Nacional de Coordinación Fiscal con las

Primary result

Total incomes minus primary expenditures as a percentage of total incomes for each province and year. Source: Dirección Nacional de Coordinación Fiscal con las Provincias.

Absenteeism

Logarithm of the percentage of absent voters in provincial elections in year $t$ and replicates the same value until a new election was performed. In most provinces elections were carried out in 2003, 2007 and 2011. Source: Ministerio del Interior y Transporte.

Edification permits

Logarithm of edification permits measured in squared kilometers and normalized by the total population in each province and year. Sources: Dirección Nacional de Coordinación Fiscal con las Provincias and INDEC

Oil prices Average retail price of different fuels and oil types (gasoil, compressed natural gas, fuels) in all gas stations in each province and year. Source: Secretaria de Energía.

Source: Own elaboration 
Table 12 Enforcement of labor regulations and compliance with social security and employment regulations one by one

\begin{tabular}{|c|c|c|c|c|c|c|c|}
\hline \multirow{3}{*}{$\begin{array}{l}\text { Dependent } \\
\text { variable }\end{array}$} & \multicolumn{7}{|c|}{$=1$ if wage employee receives } \\
\hline & $\begin{array}{l}\text { Pension } \\
\text { contributions }\end{array}$ & $\begin{array}{l}\text { Health } \\
\text { insurance } \\
\text { contributions }\end{array}$ & $\begin{array}{l}\text { Paid vacation } \\
\text { time }\end{array}$ & $\begin{array}{l}\text { Minimum } \\
\text { wage }\end{array}$ & $\begin{array}{l}\text { Annual } \\
\text { extra } \\
\text { wage }\end{array}$ & $\begin{array}{l}\text { Paid } \\
\text { sickdays }\end{array}$ & $\begin{array}{l}\text { Max weekly } \\
\text { hours }\end{array}$ \\
\hline & (1) & (2) & (3) & (4) & (5) & (6) & (7) \\
\hline \multicolumn{8}{|l|}{ Men } \\
\hline \multirow{2}{*}{$\begin{array}{l}\text { Log(enforcement } \\
\text { measure) }\end{array}$} & 0.103 & 0.104 & 0.0987 & 0.0625 & 0.102 & 0.108 & -0.0151 \\
\hline & {$[0.0346]^{* * *}$} & {$[0.0340]^{* * *}$} & {$[0.0351]^{* * *}$} & {$[0.0181]^{* * *}$} & {$[0.0352]^{* * *}$} & {$[0.0371]^{* * *}$} & {$[0.0332]$} \\
\hline Observations & 148,166 & 148,166 & 148,166 & 148,166 & 148,166 & 148,166 & 148,166 \\
\hline$R^{2}$ & 0.279 & 0.279 & 0.270 & 0.246 & 0.271 & 0.271 & 0.065 \\
\hline \multicolumn{8}{|l|}{ Women } \\
\hline \multirow{2}{*}{$\begin{array}{l}\text { Log(enforcement } \\
\text { measure) }\end{array}$} & -0.175 & -0.169 & -0.164 & -0.102 & -0.170 & -0.174 & -0.0820 \\
\hline & {$[0.100]^{*}$} & {$[0.0945]^{*}$} & {$[0.0928]^{*}$} & {$[0.0594]^{*}$} & {$[0.0968]^{*}$} & {$[0.0951]^{*}$} & {$[0.0443]^{*}$} \\
\hline Observations & 83,906 & 83,906 & 83,906 & 83,906 & 83,906 & 83,906 & 83,906 \\
\hline$R^{2}$ & 0.215 & 0.217 & 0.183 & 0.232 & 0.184 & 0.188 & 0.039 \\
\hline \multicolumn{8}{|l|}{ Included controls } \\
\hline $\begin{array}{l}\text { Individual } \\
\text { characteristics }\end{array}$ & Yes & Yes & Yes & Yes & Yes & Yes & Yes \\
\hline $\begin{array}{l}\text { Political business } \\
\text { cycle variables }\end{array}$ & Yes & Yes & Yes & Yes & Yes & Yes & Yes \\
\hline $\begin{array}{l}\text { Quality of } \\
\text { institutions } \\
\text { variable }\end{array}$ & Yes & Yes & Yes & Yes & Yes & Yes & Yes \\
\hline $\begin{array}{l}\text { Development } \\
\text { level variables }\end{array}$ & Yes & Yes & Yes & Yes & Yes & Yes & Yes \\
\hline $\begin{array}{l}\text { Demand shocks } \\
\text { variables }\end{array}$ & Yes & Yes & Yes & Yes & Yes & Yes & Yes \\
\hline $\begin{array}{l}\text { Province fixed } \\
\text { effects }\end{array}$ & Yes & Yes & Yes & Yes & Yes & Yes & Yes \\
\hline $\begin{array}{l}\text { Sector fixed } \\
\text { effects }\end{array}$ & Yes & Yes & Yes & Yes & Yes & Yes & Yes \\
\hline Year fixed effects & Yes & Yes & Yes & Yes & Yes & Yes & Yes \\
\hline $\begin{array}{l}\text { Province-time } \\
\text { trends }\end{array}$ & Yes & Yes & Yes & Yes & Yes & Yes & Yes \\
\hline
\end{tabular}


Table 13 Arrival cost of labor inspectors and enforcement of labor regulations

\begin{tabular}{|c|c|c|c|c|c|}
\hline \multirow[t]{3}{*}{ Dependent variable } & \multicolumn{5}{|c|}{ Log(enforcement measure) } \\
\hline & \multicolumn{2}{|l|}{ Men } & \multicolumn{3}{|l|}{ Women } \\
\hline & $(1)$ & $(2)$ & (3) & (4) & (5) \\
\hline \multirow[t]{2}{*}{ Log(arrival cost) ${ }^{*}$ shr04 } & -0.867 & -0.515 & -0.672 & -0.453 & -0.974 \\
\hline & {$[0.269]^{* * *}$} & {$[0.167]^{* * *}$} & {$[0.313]^{* *}$} & {$[0.180]^{* *}$} & {$[0.244]^{* * *}$} \\
\hline Individual characteristics & Yes & Yes & Yes & Yes & Yes \\
\hline Political business cycle variables & Yes & Yes & Yes & Yes & Yes \\
\hline Quality of institutions variable & Yes & Yes & Yes & Yes & Yes \\
\hline Development level variables & Yes & Yes & Yes & Yes & Yes \\
\hline Demand shocks variables & Yes & Yes & Yes & Yes & Yes \\
\hline Province fixed effects & Yes & Yes & Yes & Yes & Yes \\
\hline Sector fixed effects & Yes & Yes & Yes & Yes & Yes \\
\hline Year fixed effects & Yes & Yes & Yes & Yes & Yes \\
\hline Province-time trends & Yes & Yes & Yes & Yes & Yes \\
\hline F statistic & 10.40 & 9.46 & 9.20 & 12.62 & 16.00 \\
\hline$p$ value of underid. test & 0.0012 & 0.0020 & 0.0158 & 0.0059 & 0.0001 \\
\hline Observations & 148,166 & 148,166 & 83,906 & 83,906 & 83,906 \\
\hline$R^{2}$ & 0.697 & 0.695 & 0.733 & 0.737 & 0.708 \\
\hline
\end{tabular}

Source: Own elaboration. Notes: OLS estimations. Columns 1 and 3 show the first stage when testing for relocation decisions of firms. Columns 2 and 4 show the first stage when changing the definition of the instrument. Column 5 shows the first stage when re-weighting the sample of women. Standard errors clustered at the province-sector level in brackets

Significant at ${ }^{* * *} 1 \%, * * 5 \%$, and ${ }^{*} 10 \%$

\section{Acknowledgements}

I am grateful to participants at the 2016 IZANOECD/World Bank/UCW Workshop: Job Quality in Post-transition, Emerging and Developing Countries and 2016 LACEA Meeting for their comments. I would also like to thank the anonymous referee and the editor for the useful remarks.

Responsible editor: Denis Fougère.

\section{Funding}

Not applicable.

Availability of data and materials

Data used in this study can be accessed at http://www.indec.gob.ar/ and https://www.argentina.gob.ar/trabajo.

Author's information

Senior Researcher at the Center for Distributive, Labor and Social Studies (CEDLAS), Facultad de Ciencias Económicas, Universidad Nacional de La Plata, Argentina.

\section{Competing interests}

The IZA Journal of Labor Policy is committed to the IZA Guiding Principles of Research Integrity. The author declares that she has observed these principles.

\section{Publisher's Note}

Springer Nature remains neutral with regard to jurisdictional claims in published maps and institutional affiliations.

Received: 10 September 2017 Accepted: 29 January 2018

Published online: 08 February 2018

References

Aidt T, Tzannatos Z (2002) Unions and collective bargaining: economic effects in a global environment. World Bank, Washington, DC

Albrecht J, Navarro L, Vroman S (2009) The effects of labour market policies I an economy with an informal sector. Econ J 119(539):1105-1129

Almeida RK, Carneiro P (2009) Enforcement of labor regulation and firm size. J Comp Econ 37:28-46

Almeida RK, Carneiro P (2012) Enforcement of labor regulation and informality. Am Econ J Appl Econ 4(3):64-89 
Almeida RK, Carneiro P, Narita R (2013) Producing higher quality jobs: enforcement of mandated benefits across Brazilian cities between 1996-2007, Working paper 2013-22. Department of Economis, University of São Paulo, São Paulo

Almeida RK, Poole JP (2017) Trade and labor reallocation with heterogeneous enforcement of labor regulations. J Dev Econ 126:154-166

Almeida RK, Ronconi L (2016) Labor inspection in the developing world: stylized facts from the Enterprise survey. Ind Relat 55(3):468-489

Amengual M (2014) Pathways to enforcement: labor inspectors leveraging linkages with society in Argentina. Ind Labor Relat Rev 67(1):4-33

Arango C, Pachón A (2004) Minimum wages in Colombia: holding the middle with a bite on the poor. In: Borradores de Economía Serie 280. Banco de la República de Colombia, Bogotá

Basu AK, Chau NH, Kanbur R (2010) Turning a blind eye: costly enforcement, credible commitment and minimum wage Laws. Econ J 120:244-269

Besley T, Burgess R (2004) Can labor regulation hinder economic performance? Evidence from India. Q J Econ 119(1):91-134

Betcherman, G. (2013). "Labor market institutions: a review of the literature". Background paper for the world development report 2013

Bhorat H, Kanbur R, Mayet N (2012) Estimating the causal effect of enforcement on minimum wage compliance: the case of South Africa. Rev Dev Econ 16(4):608-623

De Paula A, Scheinkman J (2006) The informal sector, Working paper. University of Pennsylvania, Philadelphia

De Soto H (1989) The other path: the invisible revolution in the third world. HarperCollins, New York

Feldmann H (2009) The unemployment effects of labor regulation around the world. J Comp Econ 37:76-90

Feliciano Z (1998) Does the minimum wage affect employment in Mexico? East Econ J 24(2):165-180

Fields GS (2005) A guide to multisector labor market models, Social protection discussion paper series 32547 . The World Bank, Washington

Galiani S, Weinschelbaum F (2012) Modeling informality formally: households and firms. Econ Inq 50(3):821-838

Gindling TH, Crummett M (1997) Maternity leave legislation and the work and pay of women in Costa Rica. University of Maryland Baltimore County, Baltimore

Kugler, A. (2004). "The effect of job security regulations on labor market flexibility: evidence from the Colombian labor market reform". NBER working paper 10215

Loayza N (1996) The economics of the informal sector: a simple model and some empirical evidence from Latin America, Carnegie-Rochester conference series on public policy XLV, pp 129-162

Loayza N, Oviedo A, Serven L (2005) The impact of regulation on growth and informality: cross-country evidence, Policy working paper 3623. The World Bank, Washington

Meghir C, Narita R, Robin JM (2015) Wages and informality in developing countries. Am Econ Rev 105(4):1509-1546

Micco, A. and C. Pagés (2006). "The economic effects of employment protection: evidence from international industrylevel data". IZA discussion paper 2433

Ministerio de Trabajo, Empleo y Seguridad Social (2013) La Inspección del Trabajo en Argentina 2003-2012. Acciones y Resultados. Secretaría de Trabajo, Buenos Aires

Mondino G, Montoya S (2004) The effects of labor market regulations on employment decisions by firms. Empirical for Argentina. In: Heckman JJ, Pagés C (eds) Law and employment: lessons from Latin America and the Caribbean. University of Chicago Press, Chicago

Montenegro C, Pagés C (2004) Who benefits from labor market regulations? Chile 1960-1998. In: Heckman JJ, Pagés C (eds) Law and employment: lessons from Latin America and the Caribbean. University of Chicago Press

Murillo MV, Ronconi L, Schrank A (2011) Latin America labor reforms: evaluating risk and security. In: Ocampo JA, Ross (eds) The Oxford handbook of Latin American economics. Oxford University Press, Oxford

Pagés C, Montenegro C (1999) Job security and the age composition of employment: evidence from Chile, Working Paper 398. Inter-American Development Bank, Washington

Piore MJ, Schrank A (2008) Toward managed flexibility: the revival of labour inspection in the Latin world. Int Labour Rev 147(1):1-23

Ronconi L (2010) Enforcement and compliance with labor regulations. Ind Labor Relat Rev 63(4):719-736

Ronconi L (2012) Globalization, domestic institutions, and enforcement of labor law: evidence from Latin America. Ind Relat 55(1):89-105

SEDLAC (2017). Socio-economic database for Latin America and the Caribbean (CEDLAS and the World Bank)

Viollaz M (2018) Are labor inspections protecting workers' rights? Adding the evidence from size-based labor regulations and fines in Peru. International Labor Review Forthcoming. http://onlinelibrary.wiley.com/doi/10.1111/ ilr.12038/full10.1186/s40173-018-0095- 